\title{
The Usage of Mobile Learning: Comparative Studies among Technical and Vocational Education Students in Selected Universities
}

\author{
https://doi.org/10.3991/ijim.v14i05.13355 \\ Che Ghani Che Kob ${ }^{(凶)}$, Shangeetavaani Kannapiran, A. Shah \\ Universiti Pendidikan Sultan Idris, Perak, Malaysia \\ cheghanieftv.upsi.edu.my
}

\begin{abstract}
This research is conducted mainly to examine the difference among Technical and Vocational Education (TVE) students at Universiti Pendidikan Sultan Idris (UPSI) and Universiti Tun Hussein Onn Malaysia (UTHM)on their computer proficiency, knowledge on mobile learning (ML), application preferred, and attitude towards ML. Quantitative research method via questionnaire distributed to 618 participants. T-test analysis was used to obtainthe differences among students in both the universities via Statistical Package for Social Sciences (SPSS) version 23.0 for Windows. The results showed there was no difference found among these students. Hereby, ML is vital for lifelong learning and the access to mobile devices are available for everyone these days. It has made ML to be a tool to learn regardless of time and place among the students today.
\end{abstract}

Keywords-Technical and Vocational education (TVE), Mobile Learning (ML), UPSI, UTHM.

\section{Introduction}

This study here investigates the usage of ML among TVE students in both the selected universities. It clarifies the meaning of ML and enable students to explore their learning activities via usage of mobile devices. The main focus is on the usage of mobile devices among the students to accomplish their learning practices instead of just exploring on what and whether they are learning. The ubiquitous learning idea is fulfilled since mobile devices are popular among teenagers (Habboush et al., 2011). Almost every student in higher education can be seen to have a mobile phone. The portability and affordability of mobile devices leverages the form learning in ML stated by Yamaguchi (2005). The advanced mobile technologies which are available like handheld devices, wireless technologies, high bandwidth infrastructure has started to extend e-learning towards ML mentioned by Sharples (2000).

Besides, learners found that carrying a computer most of the time and searching for internet access point are the major constraints(Kurbel, 2002).Due to bandwidth and connectivity limitations the downloading of engaging content to the learners noted to 
be slow and need to upgrade mobile device frequently with data charges which could be quite high. Students might need training in the basic functions and applications of ML technologies (Cheon et al., 2012). This can also be said that there is lack of technical skills among students. These limitations on the application of ML can hinder using mobile technology widely in learning. ML via online requires a very high degree of self-motivation which is found to be lacking among our learners' attitude. Hereby, these constraints are to be examined in this study from the aspect of students' computer proficiency, knowledge on ML, application preferred, and also their attitude towards ML.

\section{Research Methodology}

\subsection{Research design}

In this study quantitative method via questionnaire consist of demographic variables, knowledge on ML among TVE students and the application preferred in mobile phone. The next part is based on their attitude towards ML. Data received were based on Likert Scale and analyzed via SPSS. The research focuses on TVE students whereby the population chosen is from faculty of technical and vocational education. Samples were from two different universities (UPSI and UTHM) and certain duration given to answer the questionnaires. Descriptive analysis was used for construct findings at each university while T-test analysis used for comparison of both the universities on each construct.

\subsection{Research validity and reliability}

Face validity was done to measure the instruments used in this research. The very first step is getting the approval from supervisor before approaching the experts of the field studied. The purpose is to make sure the developed questionnaires answer all the research questions as stated. For reliability analysis Cronbach alpha is used as the statistical tool in internal consistency. The value achieved is at sufficiently high and acceptable for items in construct attitude and for items in construct of computer proficiency, knowledge on ML, and also application preferred display an outstanding value as stated in the guide to interpretation score of Cronbach's alpha.

\section{Literature Review}

The change in technology, social and culture has transformed an evolution of human life and activity via ML where it values and defends on its own unique way. Among the advantages of ML for learners in current generation is to allow certain amount of enjoyment towards freedom and being independent (Uden, 2007). Hereby, McAlister (2009) stated millennial students are comfortable and confident towards the usage of technology and engaged with the multiple sensory related to different types 
of media used in their learning. In addition, she explained that usage of these new tools of combination on pedagogical knowledge leads to well-grounded and will engage students to explore the world continuously.

Furthermore, Williams (2006) mentioned that the mobile technologies like handheld computers and mobile phones are affordable. He adds on that the mobile devices have many functions which offers for teaching and learning purpose and also a sensible choice for educational investment. As known education of TVET is specially designed to empower learners via development of technical skills, human abilities, cognitive understanding, attitudes and work habits. This is basically to prepare learners sufficiently in the working world or practically to position themselves for selfemployment after graduation (Winer, 2000).

According to Isman and Celikli (2009), the core factors to determine students' success in participation of ML were their attitudes and computer self-efficacy. People with high computer self-efficacy were found to be more actively engaged in activities related to computer upon previous studies. They are adept in the usage of internet where mobile phones and emails are used to communicate. Even they are actively involved as online communities, skillful at downloading music, video, and other materials into their mobile devices and finding information from electronic or virtual libraries. Variety of electronic media also known as e-genres provide self-learning platform where websites are built themselves. The nature usage of technologies is unquestionable since there is a need of change for learning and teaching in the pedagogy.

The believe of people or what they know even if the beliefs of others at times not to be believed can conclude the best as "knowledge". Knowledge consists of information in an organized body. Those information form patterns In the basis kind of insights and judgements which are called as wisdom by a physical analogy Stonier (1993). Hence, wisdom is one step below knowledge and information is one step above knowledge. Information is considered raw data in knowledge. So, knowledge is a combination of information and experience from a person. Knowledge in this study will be focusing on ML. As Dickinger et al., (2005) stated that a standard built-in wireless network in mobile phones, PDA, and laptops encourage learners to access the information at anywhere.

Attitude shows definition relating to mental or neural state in readiness, organized via experience, the influence use of directive or dynamic on individual's response onto situations and all objects that is comprehensive (Allport, 1935). Furthermore, recent study which dealt with trends towards ML from the premise where three components composed attitude. The components are based on ABC (affect, behavior, and cognition) model consisting cognitive, emotional and behavioral components. In addition, attitude is according to the knowledge, experience, and skills that enable an individual to perform learning tasks effectively. The following figure illustrates the $\mathrm{ABC}$ model which was firstly proposed by Hilgard (1980). 


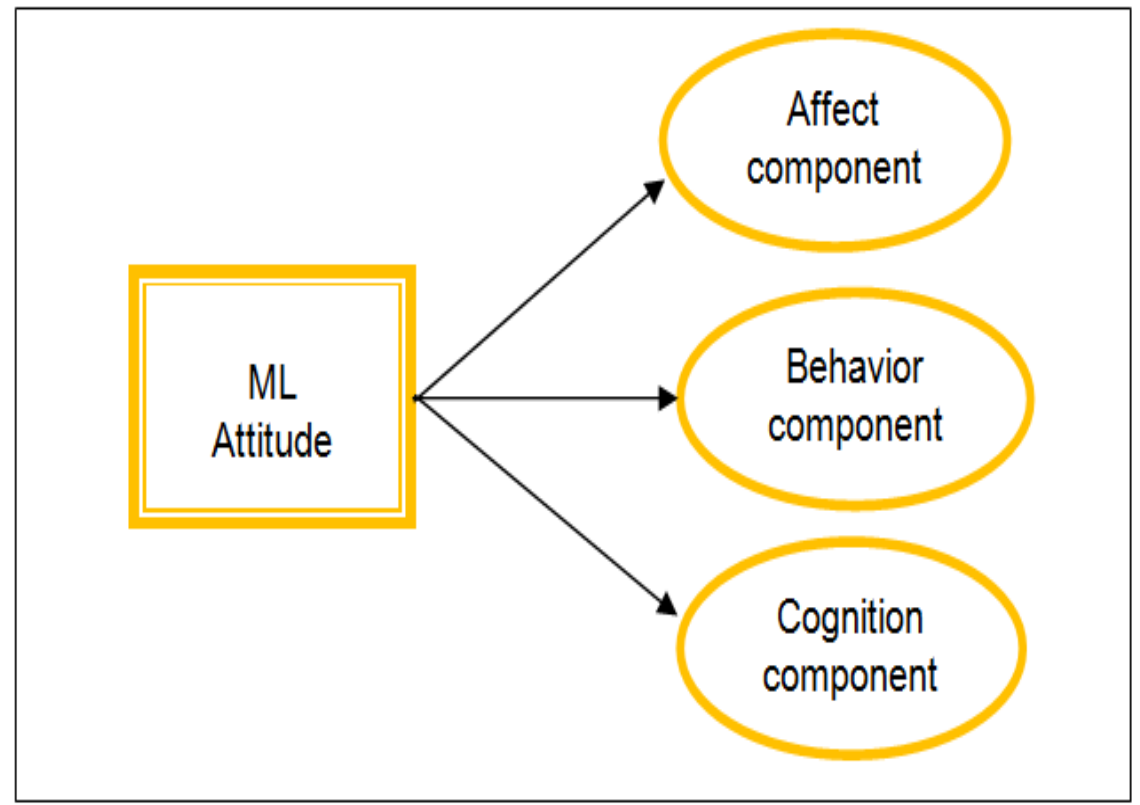

Fig. 1. The Attitude Components of ML

As in Figure 1 illustrates the three components towards ML on formulating any practices. Emotional response that expresses the degree of preference in an individual towards usage of mobile devices known as affective response. The typical tendency of behavioral or verbal indication in an individual is called the behavioral or skill intention. Cognitive process consolidates a process of cognition. An individual's process of thinking about stimuli ignites response. As such the cognitive response towards mobile is a cognitive evaluation of the user's belief about the object. Indeed, majority of the results for attitudes are from the environment of either direct experience or observational learning.

Furthermore, it is vital to determine the level of technology acceptance as well as to investigate the readiness for mobile phone technologies embracement in education from all components involving awareness, motivation, training, and courses. Adding on by Alzaza's (2012) that those who have knowledge which is sufficient and conscious of using certain technology in the environment of education were demonstrating their readiness for ML implementation.

\section{$4 \quad$ Findings}

From Table 1 can be seen that mean students based on constructs at UPSI is slightly more compared to UTHM. The spread of data deviated is similar upon the results shown since not much of difference noted. 
Table 1. Results of Mean and Standard Deviation among UPSI and UTHM Students

\begin{tabular}{|l|l|c|c|}
\hline \multicolumn{1}{|c|}{ Construct } & University & Mean & Standard Deviation \\
\hline \multirow{2}{*}{ Computer proficiency } & UPSI & 4.3966 & 0.50454 \\
\cline { 2 - 5 } & UTHM & 4.3789 & 0.52519 \\
\hline \multirow{2}{*}{ Knowledge on ML } & UPSI & 4.2231 & 0.54256 \\
\cline { 2 - 5 } & UTHM & 4.2230 & 0.52933 \\
\hline \multirow{2}{*}{ Application preferred for learning purpose } & UPSI & 4.4098 & 0.53630 \\
\cline { 2 - 5 } & UTHM & 4.3938 & 0.51226 \\
\hline Attitude towards ML & UPSI & 4.1325 & 0.54946 \\
\cline { 2 - 5 } & UTHM & 4.1063 & 0.551949 \\
\hline
\end{tabular}

As in Table 2, the results of independent sample test are interpreted. Results of Levene's test obtained was more than 0.05 for all the four constructs which means the variances are not significantly different and assumed as equal. As for t-values all the constructs showed no significant difference where the value obtained were more than 0.05 except for construct knowledge on ML the value was less than 0.05 where statistically there was significant difference.

Table 2. Results of Independent Samples Test

\begin{tabular}{|c|c|c|c|c|c|c|c|c|c|}
\hline \multirow[t]{3}{*}{ Constructs } & \multicolumn{2}{|c|}{$\begin{array}{c}\text { Levene's Test } \\
\text { for Equality of } \\
\text { Variances } \\
\end{array}$} & \multicolumn{7}{|c|}{ t-test for Equality of Means } \\
\hline & \multirow[t]{2}{*}{$F$} & \multirow[t]{2}{*}{ Sig. } & \multirow[t]{2}{*}{$t$} & \multirow[t]{2}{*}{$d f$} & \multirow[t]{2}{*}{$\begin{array}{l}\text { Sig. }(2- \\
\text { tailed })\end{array}$} & \multirow[t]{2}{*}{$\begin{array}{c}\text { Mean } \\
\text { Difference }\end{array}$} & \multirow[t]{2}{*}{$\begin{array}{l}\text { Std. Error } \\
\text { Difference }\end{array}$} & \multicolumn{2}{|c|}{$\begin{array}{l}95 \% \text { Confidence } \\
\text { Interval of the Dif- } \\
\text { ference }\end{array}$} \\
\hline & & & & & & & & Lower & Upper \\
\hline $\begin{array}{l}\text { Computer } \\
\text { proficiency }\end{array}$ & .568 & .451 & .424 & 616 & .671 & .01778 & .04191 & -.06452 & .10009 \\
\hline $\begin{array}{l}\text { Knowledge on } \\
\text { ML }\end{array}$ & .326 & .568 & .003 & 616 & .997 & .00015 & .04343 & -.08515 & .08545 \\
\hline $\begin{array}{l}\text { Application } \\
\text { preferred for } \\
\text { learning pur- } \\
\text { pose }\end{array}$ & 3.277 & .071 & .377 & 616 & .706 & .01602 & .04244 & -.06732 & .09935 \\
\hline $\begin{array}{l}\text { Attitude to- } \\
\text { wards ML }\end{array}$ & 1.668 & .197 & .605 & 616 & .545 & .02618 & .04324 & -.05873 & .11109 \\
\hline
\end{tabular}

Hereby, it is shown that there is no much difference between both the universities perhaps due to these students are being focused on the same faculty that is technical and vocational educational. Yet, the knowledge on ML differs among these students. This is perhaps because students were unable to combine the information obtained with their experience. The way of mobile devices used in m-learning among the students must be the same such as accessing Internet to complete their assignments and submitting it via e-mails.

According to McAlister (2009), students of millennial are very much convenient and confident using technology. They are able to engage with the multiple engagement of sensory relating to different media types in their learning. Therefore, can be seen that TVE students are capable of ML in their learning purposes and there is no 
much difference between the usages of MLamong these students of both the universities as mention earlier. Hence, educational technology has had a significant impact due to the emergence of revolutionary technologies.

\section{Conclusion}

ML gives a head start in the revolution of information technology among the students. Indeed, to equip them with skills not only to perform better in their studies as well as to excel in their future careers. ML is very known to acquire information upon the flexibility for students to learn at their convenience. This has been made reality with the existence of wireless mobile technology. Hence, from this study it is shown that students have the awareness to mobile technologies in learning process. The students were keen to use all sources of ML approaches through mobile devices so that access to information would be anytime and anywhere.

\section{Acknowledgement}

The authors wish to thank both universities, Universiti Pendidikan Sultan Idris (UPSI) and Universiti Tun Hussein Onn Malaysia (UTHM)for providing the data and helpful during the collection of data from participants. Indeed, we are grateful to UPSI for funding this research under 2018-0061-107-01.

\section{$7 \quad$ References}

[1] All port, G., (1935). Attitudes in Murichson, G. Lorcestor, (ed) A Hand book of social psychology, clark university press, worcester, massacausetts.

[2] Alzaza, N.S. (2012). Opportunities for utilizing mobile learning services in the Palestinian Higher Education. Retrieved August 13, 2012 from http://www.iajet.org/iajet files/vol.2/no.4/Opportunities\%20for\%20Utilizing\%20Mobile\%20Learning\%20Services\% 20in\%20the \%20Palestinian\%20Higher\%20Education.pdf

[3] Cheon, J., Sangno, L., Crooks, S.M. \& Song, J. (2012). An investigation of mobile learning readiness in higher education based on the theory of planned behavior. Computers \& Education, 59, 1054---1064. https://doi.org/10.1016/j.compedu.2012.04.015

[4] Dickinger, A., Heinzmann, P., \& Murphy, J. (2005). Mobile Environmental applications. Paper presented at the 38th Hawaii International Conference on System Science, Hawaii. https://doi.org/10.1109/hicss.2005.434

[5] Habboush, A., Nassuora, A., \& Hussein, A.-R. (2011). Acceptance of mobile learning by university students. American Journal of Scientific Research (22), 119-122.

[6] Hilgard, E.R. (1980). The trilogy of mind: Cognition, affection, and Conation. Journal of the History of Behavioral Sciences, 16, 107-117. https://doi.org/10.1002/15206696 (198004)16:2<107::aid-jhbs2300160202>3.0.co;2-y

[7] Isman, A. and Celikli, G.E. (2009). How Does Student Ability and Self-Efficacy Affect the Usage of Computer Technology? The Turkish Online Journal of Educational Technology, ISSN: 1303-6521, volume 8, Issue 1, (pp: 33-38). 
[8] Kurbel, K. (2002). Multimedia-based master's programme in business informatics in Dikshit, H.P., Garg, S., Panda, S., and VijayshriEds, Access \& Equity: Challenges for Open and Distance Learning, New Delhi: Kogan Page, pp 277-286.

[9] McAlister, A. (2009). Teaching the millennial generation. American Music Teacher, Proquest Education Journal, 13-15.

[10] Sharples. (2000). 'The design of personal mobile technologies for lifelong learning', Computers \& Education, Vol. 34, pp. 177-193. https://doi.org/10.1016/s0360-1315(99)00044-5

[11] Stonier, T. (1993). The wealth of information. London: Thames/Methuen. State University, 1996. (ED 414 446) Long, M.H. \& Porter, P.A. (1985). Group work, interlanguage talk and second language acquisition. TESOLQuarterly 19/2, 207-227. https://doi.org/10.2307/ $\underline{3586827}$

[12] Uden, L. (2007). Activity Theory for Designing Mobile Learning. Journal of Mobile Learning and Organisation, 1 (1), 81-102. https://doi.org/10.1504/ijmlo.2007.011190

[13] Williams, B. (2006). Handheld Computers and Smartphones in Secondary Schools. Eugene: International Society for Technology in Education.

[14] Winer, R. K. (2000) Rung by up the health career ladder. American Vocational Journal, 48(7), pp.18-27.

[15] Yamaguchi, 2005 Yamaguchi, T., (2005). Vocabulary learning with a mobile phone. Program of the 1Oth Anniversary Conference of Pan-Pacific Association of Applied Linguistics, Edinburgh, UK.

\section{Authors}

Che Ghani Che Kob, Department of Engineering Technology, Faculty of Technical and Vocational, Universiti Pendidikan Sultan Idris, 35900 Tanjung Malim, Perak, Malaysia cheghani@ftv.upsi.edu.my

Shangeetavaani Kannapiran, Department of Engineering Technology, Faculty of Technical and Vocational, Universiti Pendidikan Sultan Idris, 35900 Tanjung Malim, Perak, Malaysia.shangeeta27@ hotmail.com

A. Shah, Department of Engineering Technology, Faculty of Technical and Vocational, Universiti Pendidikan Sultan Idris, 35900 Tanjung Malim, Perak, Malaysi. armanshah@ftv.upsi.edu.my

Article submitted 2020-02-22. Resubmitted 2020-03-27. Final acceptance 2020-03-27. Final version published as submitted by the authors. 